\title{
Pulmonary Neuroendocrine Cell-Secreted Factors May Alter Fetal Lung Liquid Clearance
}

\author{
SHEPHALI G. GANDHI, CHRISTINE LAW, WENMING DUAN, GAIL OTULAKOWSKI, AND HUGH O’BRODOVICH
}

\begin{abstract}
CIHR Group in Lung Development [S.G.G., C.L., W.D., G.O., H.O.], Hospital for Sick Children Research Institute, Toronto, Ontario, Canada M5G 1X8; Department of Paediatrics [G.O., H.O.], University of Toronto, Toronto, Ontario, Canada M5G 1X8; Department of Pediatrics [H.O.], Stanford School of Medicine, Stanford, California 94305-5208
\end{abstract}

\begin{abstract}
The neuroendocrine system is most active at birth and may play a role in the transition from fetal to postnatal life, in particular in the lungs' transition from fluid secretion to fluid absorption. Pulmonary neuroendocrine cells do release dopamine (DA), serotonin, and gastrin-releasing peptide but their effects on lung ion and fluid transport are poorly understood. Therefore, we studied their effects on fetal distal lung explants and primary cultures of fetal distal lung epithelium (FDLE). We show that DA, but neither serotonin nor gastrin-releasing peptide, alters ion and fluid transport, in a dosedependent manner. DAs effects were abrogated by D1/D2 receptor blockers in FDLE but not in explants. Propranolol abrogated DAs effects in both models. DA increased intracellular cAMP levels in FDLE. Terbutaline, forskolin, and isobutylmethylxanthine did not increase short circuit current (Isc) in DA-treated cells, despite a further increase in cAMP. We conclude that at least one, but not all mediators released by pulmonary neuroendocrine cells alter distal lung epithelial ion transport. (Pediatr Res 65: 274-278, 2009)
\end{abstract}

$\mathrm{P}$ ulmonary neuroendocrine cells (PNEC) are located throughout the lung, either in clusters referred to as neuroepithelial bodies or as single cells, and are important in fetal lung development $(1,2)$. Further, PNEC have been observed to increase during prolonged hypoxia (3), in bronchopulmonary dysplasia (4), and in models of lung injury (5).

PNEC are the first epithelial cells to differentiate in the fetal lung, and are present in higher numbers around the time of birth, decreasing postnataly (6). They secrete many mediators, including dopamine (DA), serotonin, gastrin-releasing peptide (GRP), and somatostatin, (7-9) which may play a role in the lungs' transition to postnatal life by altering fetal lung epithelial ion and fluid transport. DA concentrations are maximal at birth (10), and it is known to alter alveolar fluid transport by increasing $\mathrm{Na}^{+}$channel and $\mathrm{Na}^{+} / \mathrm{K}^{+}$-ATPase activity $(10,11)$. Some studies suggest that serotonin may have a similar role in fluid clearance in the fetal lung (12); however, others suggest that serotonin decreases transepithelial $\mathrm{Na}^{+}$transport (13). GRP is the mammalian homologue of bombesin (isolated from frog), and has been shown to modulate ion transport in

Received July 29, 2008; accepted October 31, 2008.

Correspondence: Hugh O'Brodovich, M.D., F.R.C.P.(C.), Department of Pediatrics, Stanford School of Medicine, 300 Pasteur Drive, Room H310, Stanford, CA 943055208; e-mail: hugh.obrodovich@stanford.edu

Supported by the Heart and Stroke Foundation of Ontario Grant T5602, by the Canadian Institutes of Health Research Operating Grant MGP-25046, and Group Grant in Lung Development. the small intestine $(14,15)$ and colon (16), although its effects in the lung have not been previously studied.

The alveolar epithelium actively clears fluid from the lungs' airspaces by actively transporting $\mathrm{Na}^{+}$through apical cation permanent ion channels with $\mathrm{Cl}^{-}$and followed by water $(17,18)$. This process is physiologically important. When there is immature lung epithelial $\mathrm{Na}^{+}$transport, infants suffer from transient tachypnoea of the newborn (19) and, when combined with relative surfactant deficiency, the newborn respiratory distress syndrome (18). Similarly, studies in adults show that resolution of pulmonary edema is important for patient survival (20). Therefore, we investigated the role of several compounds secreted by PNEC on ion transport across fetal distal lung epithelial monolayers, and net fluid transport in fetal distal lung explants.

\section{METHODS}

Animals. Studies were reviewed and approved by the Hospital for Sick Children (sick kids) Animal Care committee and carried out at sick kids. ${ }^{1}$

Materials. Tissue culture media and supplements were from Invitrogen (Burlington, ON). Unless specified otherwise, other reagents and proteins were from Sigma Chemical (Oakville, ON).

Fetal distal lung epithelium primary culture and bioelectric studies. Fetal distal lung epithelium (FDLE) were isolated and grown in submersion culture on porous Transwell filters, as previously described $(21,22)$. Cells prepared using similar methods mainly contain fetal type II epithelial cells (23); however, because precursor type II cells or airways cells may also be present, we refer to these cells as FDLE. Monolayers were studied under short circuit conditions $72-96 \mathrm{~h}$ after seeding by mounting them in Ussing chambers coupled to voltage-current amplifiers as previously described $(22,24)$.

Dose-response experiments were carried out for serotonin, GRP (Bachem Scientific, Torrance, CA), and DA by sequentially increasing doses of the hormone (apical and basolateral) and recording short circuit current (Isc) after each addition. In blocker experiments, FDLE were pretreated with the blocker for $5 \mathrm{~min}$ and then treated with DA for $15 \mathrm{~min}$ before Isc was recorded. In examining the effects of the addition of terbutaline (TFI) $(\mathrm{T}, 100 \mu \mathrm{M})$, forskolin (F, $10 \mu \mathrm{M})$, and isobutylmethylxanthine (IBMX) (I, $10 \mu \mathrm{M})$ on Isc in DA-treated cells, FDLE were treated with DA for $15 \mathrm{~min}$, followed by TFI, forskolin, and IBMX (TFI) for $45 \mathrm{~min}$. Control monolayers were tested in parallel with the addition of the appropriate vehicle.

Fetal distal lung explant and net fluid studies. Pregnant CD1 mice were used to prepare fetal distal lung explants. Changes in cross-sectional area of explants were used as a surrogate measure of net fluid absorption or secretion as described (21). Data are presented as the change in the size of the explants, relative to the change for the vehicle-treated explants derived from the same lung.

Abbreviations: DA, dopamine; FDLE, fetal distal lung epithelium; GRP, gastrin-releasing peptide; IBMX, isobutylmethylxanthine; Isc, short circuit current; PNEC, pulmonary neuroendocrine cells; TFI, terbutaline forskolin isobutylmethylxanthine 
Measurement of cAMP levels. FDLE seeded on Transwell inserts were treated with DA for $5 \mathrm{~min}$, followed by TFI for $5 \mathrm{~min}$. Control cells treated with 1) neither DA nor TFI, 2) DA, or 3) TFI in parallel. Cells were then lysed in $0.1 \mathrm{M} \mathrm{HCl}$ for $10 \mathrm{~min}$. Lysates were centrifuged at $600 \mathrm{~g}$ for $10 \mathrm{~min}$. The supernatant's concentration of cAMP was measured using the Format A cAMP "PLUS" enzyme Immunoassay Kit (Biomol International, Plymouth Meeting, PA). Data were analyzed using SOFTMax PRO Software (Molecular Devices, Sunnyvale, CA), and the standard curve was fitted to a fourparameter logistical model, and used to calculate cAMP levels in samples. Protein levels for each sample were measured using the Bio-Rad Protein Assay Reagent (Bio-Rad Laboratories, Hercules, CA), and used to normalize measured cAMP levels.

Statistical analysis. Data are reported as mean \pm SE (SEM). Statistical significance was determined using analysis of variance, repeated measures analysis of variance, or the $t$ test with Bonferroni's correction as indicated $(p<0.05)$. When parametric assumptions of normality and/or equality of variance between the groups were not present appropriate nonparametric tests were used instead.

\section{RESULTS}

Serotonin and GRP do not alter ion or fluid transport in the rat fetal distal lung. FDLE were placed into Ussing chambers and treated sequentially with increasing doses of serotonin $\left(10^{-6}\right.$ to $\left.10^{-4} \mathrm{M}\right)$ but even after $10^{-4} \mathrm{M}$ serotonin, the percent baseline Isc was not different from that of vehicletreated control cells $(p>0.05$, Fig. 1A). Consistent with these observations, serotonin did not affect the change in size of explants over a 24 -h treatment (Fig. $1 B$ ). We also found that
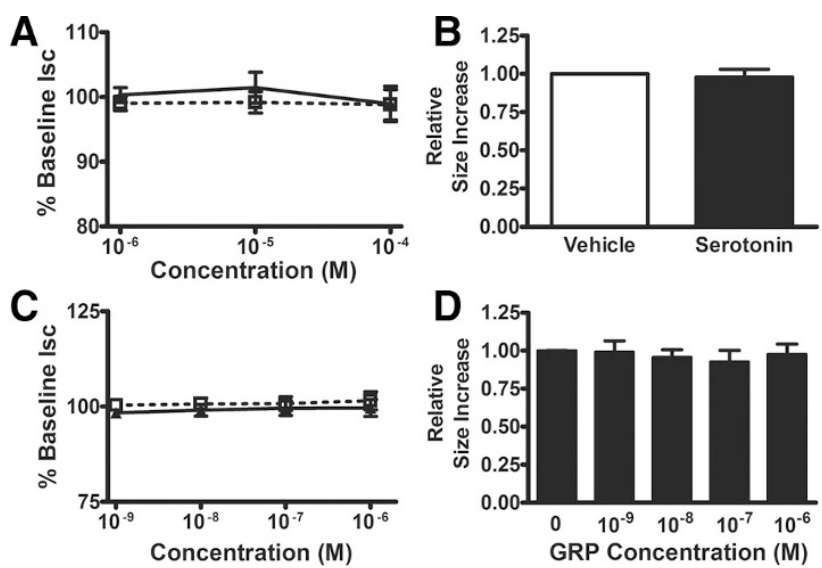

Figure 1. Neither serotonin nor GRP alters ion or fluid transport in the fetal distal lung. (A) Serotonin was added to FDLE monolayers $(\mathbf{\Delta})$ and control monolayers received corresponding volumes of vehicle $(\square)$. Data (mean \pm SEM) are presented as percent Isc relative to baseline Isc for each monolayer. (Raw baseline Isc values for vehicle and serotonin groups were $6.1 \pm 0.32$ $\mu \mathrm{A} / \mathrm{cm}^{2}$ and $6.1 \pm 0.31 \mu \mathrm{A} / \mathrm{cm}^{2}$, respectively). Serotonin had no effect on Isc in FDLE. $\left(R=941 \pm 51.3 \Omega \cdot \mathrm{cm}^{2}\right.$, PD $\left.>1.0 \mathrm{mV}, n=10-11\right)$. (B) Fetal distal lung explants were treated with either $10^{-4} \mathrm{M}$ serotonin or vehicle. Data are plotted as the size change relative to vehicle-treated control explants from the same lung, by the end of the treatment period. (Raw percent size change for vehicle-treated cells was $50.2 \pm 3.90 \%$ ). Serotonin had no effect on explant expansion when compared with explants treated with the vehicle alone. $(n=12)$. (C) GRP was added in increasing concentrations to FDLE (A) and control monolayers were treated with vehicle $(\square)$. Data are presented as percent Isc relative to the baseline for each monolayer. (Raw baseline Isc values for vehicle and GRP groups were $4.7 \pm 0.31 \mu \mathrm{A} / \mathrm{cm}^{2}$ and $4.5 \pm 0.39$ $\mu \mathrm{A} / \mathrm{cm}^{2}$, respectively). GRP did not alter Isc in FDLE. $(R=891 \pm 21.9$ $\left.\Omega \cdot \mathrm{cm}^{2}, \mathrm{PD}>1.0 \mathrm{mV}, n=8\right)$. (D) Fetal distal lung explants were treated with GRP (up to $10^{-6} \mathrm{M}$ ). GRP did not affect explant growth at any of the doses tested. Data are plotted as the size change relative to the vehicle control from the same lung, during treatment period. (Raw percent size change for vehicle-treated cells was $50.2 \pm 2.07 \%)$. GRP had no effect on explant size. $(n=9-21)$.
GRP $\left(10^{-9}\right.$ to $\left.10^{-6} \mathrm{M}\right)$ did not have an effect on Isc or explant size (Fig. 1D). Therefore, neither serotonin nor GRP alter distal lung ion and fluid transport whether FDLE are in monolayers or when they are in contact with mesenchymal cells and interstitial matrix.

Dopamine alters ion transport in the rat fetal distal lung. We have tested a range of doses for DA from physiologic to pharmacological. FDLE exposed to $10^{-4} \mathrm{M}$ DA had significantly increased transepithelial Isc compared with the control monolayers $(p<0.01$, Fig. $2 A)$. DA tended to increase both the amiloride-insensitive and amiloride-sensitive current (Fig. $2 A$ ); however, neither individually reached statistical significance. DA induced a dose-dependent increase in Isc whereas vehicle-exposed monolayers showed no change (Fig. 2B). Thus, DA can increase epithelial ion transport in the fetal distal lung.

Dopamine alters net fluid transport in fetal distal lung explants. To demonstrate the effects of DA in a model where the epithelia remained in contact with the components of the lungs' interstitium, we studied the effects of DA treatment on fetal distal lung explants. Explants treated with DA showed less expansion than control explants (Fig. 2C). This effect was dose dependent, with no significant effect on explant expansion at $10^{-7} \mathrm{M} \mathrm{DA}$, but progressively greater inhibition at $10^{-5}$ and $10^{-4} \mathrm{M}$ (Fig. 2C). These data suggest that DA reduces net fluid secretion in fetal distal lung explants either by decreasing the secretion of cells or by inducing a subpopulation of epithelial to initiate $\mathrm{Na}^{+}$and fluid absorption.

Dopamine effects are blocked by dopamine receptor blockers in FDLE, but not in distal lung explants. To examine the mechanism through which DA alters fluid transport in the lung, we examined the ability of various receptor antagonists to block its effects. We pretreated FDLE monolayers with a D1 type DA receptor blocker (SCH 23390, $10 \mu \mathrm{M}$ ) and a D2 type DA receptor blocker (S (-) sulpiride, $10 \mu \mathrm{M}$ ) or vehicle (DMSO), for a period of $5 \mathrm{~min}$, and then treated with DA $\left(10^{-4} \mathrm{M}\right)$ or vehicle $\left(\mathrm{H}_{2} \mathrm{O}\right)$ for $15 \mathrm{~min}$. After this treatment, cells treated with vehicle alone, D1/D2 blockers alone or D1/D2 blockers with DA, all demonstrated similar Isc relative to the baseline levels (Fig. 3A). The Isc in DA-treated group increased to $135.5 \pm 3.41 \%$ of baseline whereas the group treated with DA and D1/D2 blockers reached only $107.0 \pm$ $4.507 \%$ of baseline Isc, and was significantly different from cells treated with DA alone ( $p<0.05$, Fig. $3 A)$. Thus, D1/D2 blockers abrogated the DA-induced increase in Isc by FDLE monolyers. In contrast, when fetal distal lung explants were treated with DA D1 and D2 receptor blockers had no effect (Fig. 3B).

$\beta$-adrenergic receptor blockers modify the effect of dopamine. Because at higher doses, DA can stimulate $\beta$-adrenergic receptors (25), we questioned whether propranolol, a competitive $\beta$-receptor blocker, could inhibit DA's effects. FDLE were treated with propranolol $(10 \mu \mathrm{M})$ or vehicle (DMSO) for $5 \mathrm{~min}$ and then with DA $\left(10^{-4} \mathrm{M}\right)$ or vehicle $\left(\mathrm{H}_{2} \mathrm{O}\right)$ for 15 min. Similar to D1/D2 blockers, propranolol abrogated the effect of DA on FDLE monolayers. Isc was not significantly different from the baseline Isc in cells treated with DA and propranolol (110.4 $\pm 2.793 \%$ of baseline Isc), whereas there were significant increases in Isc in cells treated with DA alone $(126.0 \pm 8.52 \%$ of baseline Isc, $p<0.05$, Fig. $4 A)$. After 

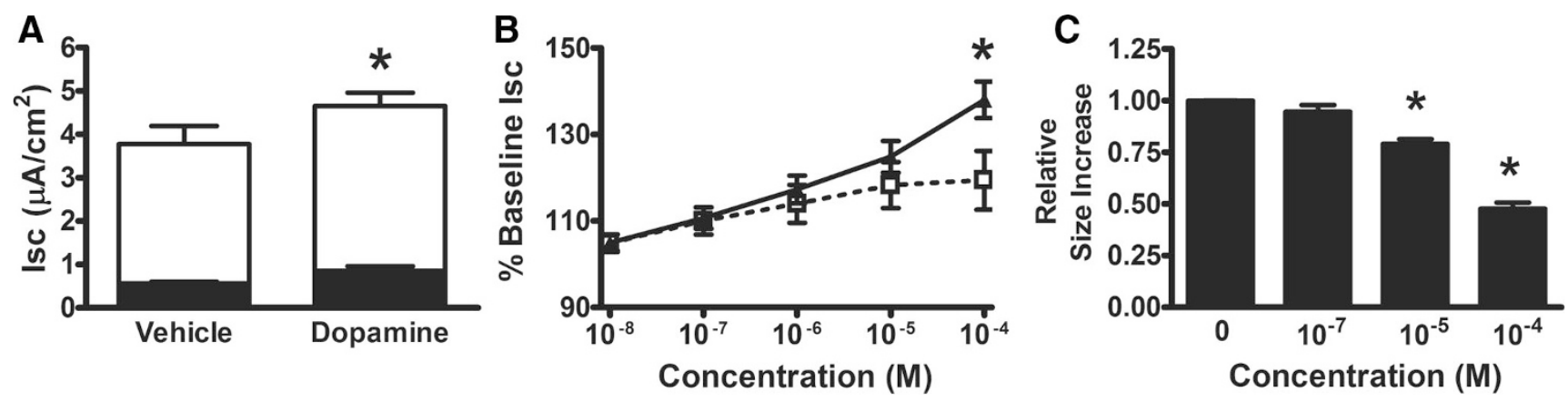

Figure 2. Dopamine increases ion transport across FDLE monolayers, and induces fluid absorption in fetal distal lung explants. (A) FDLE exposed to $10^{-4}$ M dopamine significantly increased Isc ( ${ }^{*} p<0.01$ for dopamine, with no significant change in control cells, by repeated measures ANOVA). Dopamine tended to increase both AIC ( $\square)$ and ASC $(\square)$ components of Isc. $\left(R=1732 \pm 200.0 \Omega * \mathrm{~cm}^{2}\right.$, PD $\left.>1.0 \mathrm{mV}, n=10\right)$. (B) Dopamine increases Isc in FDLE in a dose-dependent manner, and this effect reached significance at the highest dose tested ( ${ }^{*} p<0.05$, dopamine $v s$. control). Raw baseline Isc values for vehicle ( $\square$ ) and dopamine $(\mathbf{\Delta})$ groups were $5.7 \pm 0.46 \mu \mathrm{A} / \mathrm{cm}^{2}$ and $5.9 \pm 0.30 \mu \mathrm{A} / \mathrm{cm}^{2}$, respectively. $\left(R=1373 \pm 112.5 \Omega \cdot \mathrm{cm}^{2}, \mathrm{PD}>1.0 \mathrm{mV}, n=20-24\right)$. $(C)$ Fetal distal lung explants were treated with increasing concentrations of dopamine. Dopamine treatment decreased the rate of expansion of lung explants, and this response was dose dependent. Raw percent size change $24-48 \mathrm{~h}$ for vehicle-treated cells was $46.6 \pm 1.26 \%$. $(n=12-24$, * $p<0.01$ relative to $0 \mathrm{M}$ dopamine).
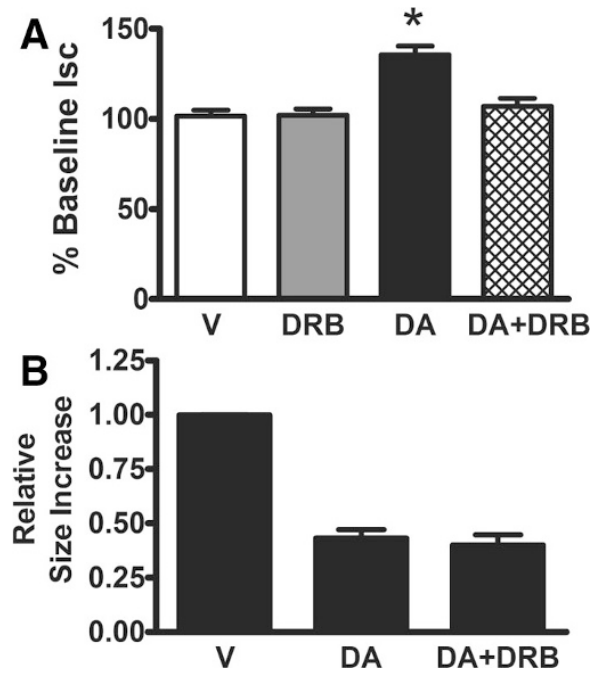

Figure 3. Dopamine receptor blockers inhibit dopamine effects on FDLE monolayers but not on fetal distal lung explants. (A) FDLE in Ussing chambers were treated with dopamine receptor blockers (DRB: D1 dopamine receptor blocker SCH-23390 $(10 \mu \mathrm{M})+\mathrm{D} 2$ receptor blocker $\mathrm{S}(-)$ sulpiride $(10 \mu \mathrm{M}))$, and then with dopamine. Data are reported as percent Isc after treatment, relative to the baseline value for each group. Dopamine receptor blockers inhibited the effect of dopamine in FDLE $(* p<0.05$, DA $v s$. DA + DRB, $n=10-11)$. (B) Fetal distal lung explants were treated with vehicle alone $(\mathrm{V})$ or to dopamine $\left(\mathrm{DA}, 10^{-4} \mathrm{M}\right)$ in the presence or absence of dopamine receptor blockers (DRB: D1 dopamine receptor blocker SCH$23390(10 \mu \mathrm{M})+\mathrm{D} 2$ receptor blocker $\mathrm{S}(-)$ sulpiride $(10 \mu \mathrm{M}))$. Dopamine receptor blockers did not alter dopamine effects on distal lung explants. Raw percent size change for vehicle-treated cells was $53.3 \pm 2.05 \%$. $(n=8)$.

treatment, cells treated with vehicle alone or propranolol alone, both demonstrated similar Isc relative to the baseline levels (Fig. 4A). Thus, treatment with propranolol before treatment with DA also abrogated the DA-induced increase in Isc. When fetal distal lung explants were treated with DA in the presence of propranolol, DA's effects were partially abrogated (Fig. 4B). This suggests that DA exerts its effects on fluid transport in the lung through $\beta$-adrenergic receptormediated pathways. In an attempt to block the portion of the DA activity still remaining in propranolol-treated explants, DA effects were also measured in explants simultaneously treated with D1/D2 blockers, propranolol and phentalomine

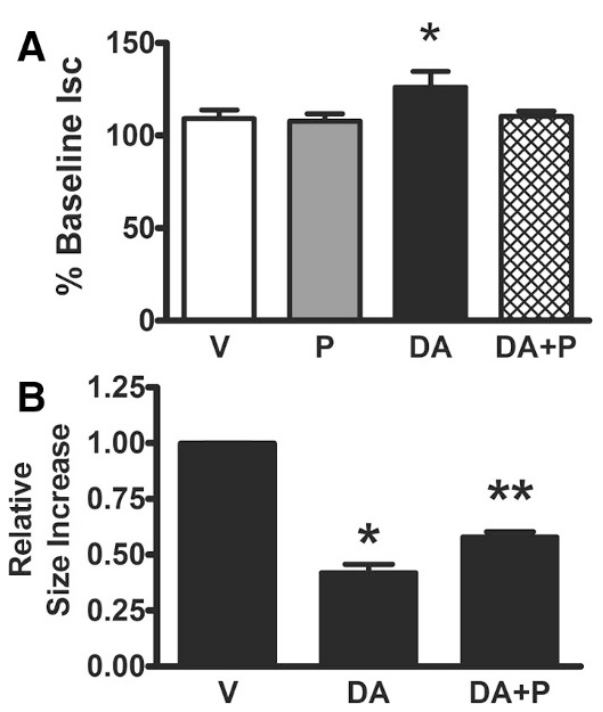

Figure 4. Propranolol inhibits the effects of dopamine. (A) FDLE treated with propranolol $(\mathrm{P}, 10 \mu \mathrm{M})$ followed by dopamine. Data are reported as percent Isc after treatment, relative to the baseline value for each group. Propranolol inhibited the effect of dopamine $(* p<0.05$, DA $v s$. DA $+\mathrm{P}, n=$ 6-7). (B) Lung explants were treated with vehicle alone (V) or to dopamine $\left(\mathrm{DA}, 10^{-4} \mathrm{M}\right)$ in the absence or presence of propranolol $(\mathrm{P}, 10 \mu \mathrm{M})$. Dopamine's effect was partially inhibited when propranolol was present. Raw percent size change for vehicle-treated cells was $64.8 \pm 2.04 \%$. $(n=16, * p<$ 0.01 relative to vehicle group, $* * p<0.05$ relative to dopamine group).

( $\alpha$-adrenergic receptor blocker). The addition of these other blockers did not further block DA effects compared with propranolol alone (data not shown).

Terbutaline, Forskolin, and IBMX increase cAMP levels but not Isc in dopamine-treated cells. To determine whether the increased Isc after DA treatment could be further increased by additional stimulation of the $\beta$-agonist cAMP signal transduction pathway, we investigated the effects of adding TFI, forskolin, and IBMX (TFI) to DA-treated cells. TFI could increase Isc in control monolayers $(p<0.05$, Fig. $5 A)$ but not in monolayers already exposed to DA, $(p>0.05$, Fig. $5 A)$. This suggests that Isc is already maximally induced in DAtreated cells. To explore this possibility further, we looked at the steady-state levels of cAMP in response to DA and TFI treatment (Fig. 5B). DA-treated cells had higher cAMP levels 


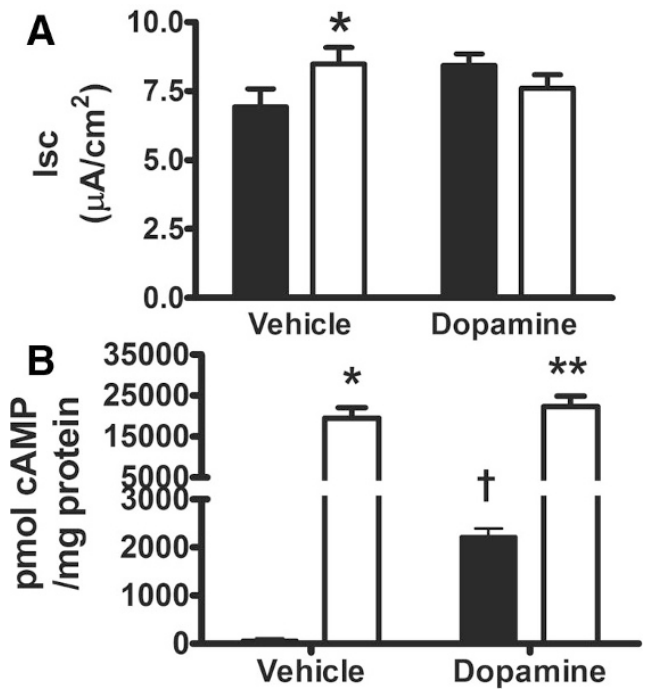

Figure 5. Dopamine-treated FDLE do not further increase Isc in response to terbutaline, forskolin and IBMX. (A) FDLE monolayers were treated with dopamine $\left(10^{-4} \mathrm{M}\right)$ and then TFI $(\square, 100 \mu \mathrm{M}$ terbutaline, $10 \mu \mathrm{M}$ forskolin, $10 \mu \mathrm{M}$ IBMX), or appropriate vehicle controls (ם). In control cells not exposed to dopamine, addition of TFI resulted in an increase in Isc $(* p<$ $0.05)$. This increase was not observed in cells treated with dopamine before TFI treatment. ( $R=1373 \pm 112.5 \Omega \cdot \mathrm{cm}^{2}$, PD $\left.>1.0 \mathrm{mV}, n=20-24\right)$. $(B)$ FDLE monolayers were treated with dopamine $\left(10^{-4} \mathrm{M}\right)$ and then TFI (100 $\mu \mathrm{M}$ ) terbutaline, $10 \mu \mathrm{M}$ forskolin, $10 \mu \mathrm{M}$ IBMX), or appropriate vehicle controls, similar to Ussing experiments, with different treatment times (see methods section). Cells were lysed and the lysate was assayed for cAMP levels. Measured cAMP levels were normalized to the protein concentration in each sample $(n=7-8)$. Dopamine treatment increased cAMP levels in FDLE ( $\dagger p<0.01$, relative to vehicle), but not to the level seen after treatment. Addition of TFI resulted in large increases in cAMP levels in both cells treated with dopamine $(* * p<0.01$, relative to TFI dopamine), and control cells $(* p<0.01$, relative to TFI vehicle).

than control cells $(p<0.01)$. TFI treatment further increased intracellular cAMP levels in both DA-treated cells and vehicle-treated cells $(p<0.01)$. After TFI treatment, there was no significant difference in the final cAMP concentration between DA treated and control cells (Fig. 5B).

\section{DISCUSSION}

Conditions such newborn respiratory distress syndrome and transient tachypnoea of the newborn are associated with significant morbidity and mortality among newborns. Both of these conditions are associated with deficient lung $\mathrm{Na}^{+}$and liquid clearance (19). Because clearance of airspace fluid is related to patient outcomes in adults (20), strategies to augment airspace fluid clearance in the perinatal airspace are needed. Therefore, we evaluated several factors secreted by PNEC by supplementing media with serotonin, DA, or GRP in distal lung cell and organotypic cultures, similar to the effect of PNEC secretion into the developing lung lumen.

DA increased ion transport across FDLE monolayers and reduced net fluid secretion in distal lung explants in a dosedependent manner. Although only small increases in net ion transport across FDLE monolayers were observed, explants exhibited 50\% less expansion over $24 \mathrm{~h}$ after DA treatment, suggesting that DAs effects may be of biologic significance. Our data are consistent with previous findings that DA in- creases fluid clearance in an isolated lung model $(11,26)$, and activates amiloride-sensitive ion transport in alveolar type I cells (27). Our dose-response studies showed small effects of DA at physiologic doses of DA $\left[10^{-8} \mathrm{M}\right.$ to $\left.10^{-7} \mathrm{M}(28)\right]$, although the effects were not large enough to reach statistical significance. Further studies were conducted using $10^{-4} \mathrm{M}$ DA, which gave a larger effect, so that effects of inhibitors could be observed more easily. These concentrations are still comparable with those used in other similar studies, for example, $10^{-4} \mathrm{M}$ DA caused strong reabsorption of lung liquid in vitro, in isolated guinea pig (10) and rat (29) lungs.

At different doses, DA stimulates dopaminergic receptors, $\alpha$-adrenergic receptors, and $\beta$-adrenergic receptors. We found that DAs effects in FDLE were inhibited using either DA- or $\beta$-adrenergic-specific blockers. Because the D1/D2 blockers used are highly selective for DA receptors [IC50s for $\beta$-adrenergic receptors $>10^{4} \mathrm{nM}(30,31)$ ], this suggests that simultaneous stimulation of both receptors may be necessary to elicit an increase in Isc. In contrast, in fetal distal lung explants, only propranolol abrogated DAs effect and no further inhibition could be achieved by adding additional blockers specific to DA or $\alpha$-adrenergic receptors, suggesting that effects in explants are mediated exclusively via $\beta$-adrenergic receptors. Both these models are derived from the fetal distal lung; however, the exact population of cells in each system differs. FDLE monolayers contain predominately type II alveolar epithelia (ATII). In contrast, explants contain multiple cell types [ATII, alveolar type I (ATI), clara cells], lie on their native basement membrane, and are exposed to mesenchymal cells. Both the proportion of cell types and intercellular interactions may explain the differences we observed between FDLE monolayers and distal lung explants in response to DA. Further, differences between rat FDLE and mouse lung explants may be explained by species differences. Alternatively, ion transport measurements in FDLE were completed after a short-term exposure to DA ( $\sim 15 \mathrm{~min})$, whereas explants were exposed to DA for $\sim 24 \mathrm{~h}$ before measurement. It is possible that pathways activated by a short-term exposure differ from those activated after a longer exposure.

Although we were able to completely inhibit DAs effect with pharmacologic receptor blockers in FDLE, we were only able to partially block DAs effect in explants. Adding inhibitors for dopaminergic receptors and $\alpha$-adrenergic receptors to propranolol-treated explants did not further inhibit DAs effect. Although this difference between the models was surprising, there are a number of potential explanations. Because of differences in the experimental conditions, time courses and cell types present, variations in the stability of these compounds, in their nonspecific binding to cell or culture components, or in their rates of diffusion of through the explant may contribute to this effect.

Studies in isolated adult rat lungs have demonstrated that DA stimulates lung fluid absorption $(10,29)$. However, there is some controversy regarding the specific mechanisms involved. In isolated adult rat lungs, SCH 23390, but neither S(-) sulpiride nor propranolol inhibited DAs effect suggesting the D1 DA receptor pathway is involved (29). In contrast, increased lung liquid absorption was mediated through D2 
receptors in fetal guinea pig lung after a short-term exposure to DA $(\sim 1 \mathrm{~h})(10)$. Our experiments showing that the DAinduced increase in Isc can be blocked with D1/D2 receptor blockers are consistent with these reports. In addition, our experiments with propranolol suggest that both DA receptor and $\beta$-adrenergic receptor signaling are required to mediate DAs effect on ion transport in isolated rat FDLE, and that $\beta$-adrenergic receptors are also important for DAs effect on mouse distal lung explants.

In contrast to DA, neither serotonin nor GRP-affected ion transport in FDLE, or fluid transport in fetal distal lung explants at any of the doses tested in this study. Others have reported that serotonin and GRP from the same manufacturers are biologically active when used in other unrelated models $(32,33)$. Our results contrast with other reports investigating the effects of these compounds on lung epithelia. Previous work using sheep tracheal epithelium mounted in Ussing chambers showed that mucosal treatment with serotonin inhibited amiloride-sensitive Isc (34), and similar effects have been reported in the baboon bronchus and rat trachea (35). In contrast, Chua and Perks (12) showed that serotonin inhibited fluid production and stimulated absorption in an isolated fetal guinea pig lung. These previous studies and our current findings highlight potential differences to be found depending on age, species, and/or regions of the lung studied. Bombesin modulates ion transport in other tissues but its action in the lung has not been previously investigated. Bombesin increases $\mathrm{Na}^{+}$entry and $\mathrm{Na}^{+} / \mathrm{K}^{+}$-ATPase activity in Swiss $3 \mathrm{~T} 3$ cells (36); however, these studies in 3T3 did not evaluate transcellular $\mathrm{Na}^{+}$transport. Several groups have demonstrated that GRP induces a transient increase in Isc in the small intestine $(14,15)$ and colon (16). In human endometrial epithelium, treatment with bombesin or GRP resulted in rapid stimulation of Isc (37).

In two fetal distal lung models, DA increased ion transport and reduced net fluid secretion, but neither serotonin nor GRP were found to have similar effects in this study. Our data support earlier findings that DA increases liquid clearance in both the rat and mouse lung, and provide insight into the mechanisms through which these effects may occur.

Acknowledgment. We thank Dr. Ernest Cutz for his suggestion and encouragement to pursue an improved understanding of the effect of mediators released by neuroendocrine cells on the ion transport by fetal distal lung epithelium.

\section{REFERENCES}

1. Hoyt RF Jr, Sorokin SP, McDowell EM, McNelly NA 1993 Neuroepithelial bodies and growth of the airway epithelium in developing hamster lung. Anat Rec 236:15-22

2. Linnoila RI 2006 Functional facets of the pulmonary neuroendocrine system. Lab Invest $86: 425-444$

3. Keith IM, Will JA 1982 Dynamics of the neuroendocrine cell-regulatory peptide system in the lung. Specific overview and new results. Exp Lung Res 3:387-402

4. Johnson DE, Anderson WR, Burke BA 1993 Pulmonary neuroendocrine cells in pediatric lung disease: alterations in airway structure in infants with bronchopulmonary dysplasia. Anat Rec 236:115-119

5. Peake JL, Reynolds SD, Stripp BR, Stephens KE, Pinkerton KE 2000 Alteration of pulmonary neuroendocrine cells during epithelial repair of naphthalene-induced airway injury. Am J Pathol 156:279-286

6. Moosavi H, Smith P, Heath D 1973 The Feyrter cell in hypoxia. Thorax 28:729-741

7. Van Lommel A, Bolle T, Fannes W, Lauweryns JM 1999 The pulmonary neuroendocrine system: the past decade. Arch Histol Cytol 62:1-16
8. Scheuermann DW 1997 Comparative histology of pulmonary neuroendocrine cell system in mammalian lungs. Microsc Res Tech 37:31-42

9. Cutz E, Yeger H, Pan J 2007 Pulmonary neuroendocrine cell system in pediatric lung disease-recent advances. Pediatr Dev Pathol 10:419-435

10. Chua BA, Perks AM 1998 The effect of dopamine on lung liquid production by in vitro lungs from fetal guinea-pigs. J Physiol 513:283-294

11. Barnard ML, Olivera W, Rutschman DM, Bertorello AM, Katz AI, Sznaider JI 1997 Dopamine stimulates sodium transport and liquid clearance in rat lung epithelium. Am J Respir Crit Care Med 156:709-714

12. Chua BA, Perks AM 1999 The pulmonary neuroendocrine system and drainage of the fetal lung: effects of serotonin. Gen Comp Endocrinol 113:374-387

13. Tamaoki J, Chiyotani A, Takemura H, Konno K 1997 5-Hydroxytryptamine inhibits $\mathrm{Na}$ absorption and stimulates $\mathrm{Cl}$ secretion across canine tracheal epithelial sheets. Clin Exp Allergy 27:972-977

14. Riviere PJ, Sheldon RJ, Malarchik ME, Burks TF, Porreca F 1990 Effects of bombesin on mucosal ion transport in the mouse isolated jejunum. J Pharmacol Exp Ther 253:778-783

15. Chandan R, Newell SM, Brown DR 1988 Actions of gastrin-releasing peptide and related mammalian and amphibian peptides on ion transport in the porcine proximal jejunum. Regul Pept 23:1-14

16. Traynor TR, O'Grady SM 1996 Regulation of colonic ion transport by GRP. I. GRP stimulates transepithelial K and Na secretion. Am J Physiol 270:C848-C858

17. Matalon S, O'Brodovich H 1999 Sodium channels in alveolar epithelial cells: molecular characterization, biophysical properties, and physiological significance. Annu Rev Physiol 61:627-661

18. O'Brodovich H 2004 Deficient $\mathrm{Na}+$ channel expression in newborn respiratory distress syndrome. Pediatr Pulmonol Suppl 26:141-142

19. Gowen CW, Lawson EE, Gingras J, Boucher R, Gatzy JT, Knowles M 1988 Electrical potential difference and ion transport across nasal epithelium of term neonates: correlation with mode of delivery, transient tachypnea of the newborn, and respiratory rate. J Pediatr 113:121-127

20. Ware LB, Matthay MA 2001 Alveolar fluid clearance is impaired in the majority of patients with acute lung injury and the acute respiratory distress syndrome. Am J Respir Crit Care Med 163:1376-1383

21. Elias N, Rafii B, Rahman M, Otulakowski G, Cutz E, O'Brodovich H 2007 The role of alpha-, beta-, and gamma-ENaC subunits in distal lung epithelial fluid absorption induced by pulmonary edema fluid. Am J Physiol Lung Cell Mol Physiol 293:L537L545

22. Gandhi SG, Rafii B, Harris MS, Garces A, Mahuran D, Chen XJ, Bao HF, Jain L, Eaton DC, Otulakowski G, O'Brodovich H 2007 Effects of cardiogenic edema fluid on ion and fluid transport in the adult lung. Am J Physiol Lung Cell Mol Physiol 293:L651-L659

23. Post M, Smith BT 1988 Histochemical and immunocytochemical identification of alveolar type II epithelial cells isolated from fetal rat lung. Am Rev Respir Dis 137:525-530

24. O’Brodovich H, Rafii B, Post M 1990 Bioelectric properties of fetal alveolar epithelial monolayers. Am J Physiol 258:L201-L206

25. Goldberg LI 1972 Cardiovascular and renal actions of dopamine: potential clinical applications. Pharmacol Rev 24:1-29

26. Saldias FJ, Comellas AP, Pesce L, Lecuona E, Sznajder JI 2002 Dopamine increases lung liquid clearance during mechanical ventilation. Am J Physiol Lung Cell Mol Physiol 283:L136-L143

27. Helms MN, Self J, Bao HF, Job LC, Jain L, Eaton DC 2006 Dopamine activates amiloride-sensitive sodium channels in alveolar type I cells in lung slice preparations. Am J Physiol Lung Cell Mol Physiol 291:L610-L618

28. Buhler HU, Da PM, Haefely W, Picotti GB 1978 Plasma adrenaline, noradrenaline and dopamine in man and different animal species. J Physiol 276:311-320

29. Barnard ML, Ridge KM, Saldias F, Friedman E, Gare M, Guerrero C, Lecuona E, Bertorello AM, Katz AI, Sznajder JI 1999 Stimulation of the dopamine 1 receptor increases lung edema clearance. Am J Respir Crit Care Med 160:982-986

30. Chivers JK, Gommeren W, Leysen JE, Jenner P, Marsden CD 1988 Comparison of the in-vitro receptor selectivity of substituted benzamide drugs for brain neurotransmitter receptors. J Pharm Pharmacol 40:415-421

31. Cross AJ, Mashal RD, Johnson JA, Owen F 1983 Preferential inhibition of ligand binding to calf striatal dopamine D1 receptors by SCH 23390. Neuropharmacology 22:1327-1329

32. Mulkey DK, Rosin DL, West G, Takakura AC, Moreira TS, Bayliss DA, Guyenet PG 2007 Serotonergic neurons activate chemosensitive retrotrapezoid nucleus neurons by a pH-independent mechanism. J Neurosci 27:14128-14138

33. Zavros Y, Fleming WR, Shulkes A 1999 Concurrent elevation of fundic somatostatin prevents gastrin stimulation by GRP. Am J Physiol 276:G21-G27

34. Graham A, Alton EW, Geddes DM 1992 Effects of 5-hydroxytryptamine and 5-hydroxytryptamine receptor agonists on ion transport across mammalian airway epithelia. Clin Sci (Lond) 83:331-336

35. Legris GJ, Will PC, Hopfer U 1982 Inhibition of amiloride-sensitive sodium conductance by indoleamines. Proc Natl Acad Sci USA 79:2046-2050

36. Mendoza SA, Schneider JA, Lopez-Rivas A, Sinnett-Smith JW, Rozengurt E 1986 Early events elicited by bombesin and structurally related peptides in quiescent Swiss $3 \mathrm{~T} 3$ cells. II. Changes in $\mathrm{Na}+$ and $\mathrm{Ca} 2+$ fluxes, $\mathrm{Na}+/ \mathrm{K}+$ pump activity, and intracellular pH. J Cell Biol 102:2223-2233

37. Matthews CJ, Redfern CP, Thomas EJ, Hirst BH 1993 Bombesin and gastrinreleasing peptide stimulate electrogenic ion transport in cultured human endometrial epithelial cell layers. Exp Physiol 78:715-718 